\title{
Sinkhole Hazard Caused by Inactive Mining Shafts as Illustrated by a Selected Example
}

\author{
Piotr STRZAłKOWSKI ${ }^{1}$
}

\begin{abstract}
Loss of stability of shafts liquidated in the past is a frequent cause of sinkhole creation on the surface. This manuscript presents such a case study. The sinkhole was created shortly after intense rainfall, so it can be assumed that displacement of the rock material in the shaft took place, i.e. the phenomenon of suffusion. One of the research aims was to confirm the assumption about the displacement of rock material filling the shaft on the basis of selected methods of sinking forecasting. Ex post forecast sinkhole creation was conducted using two methods (Bell and finite element method). It was assumed that the material filling the shaft lowered itself to a height determined on the basis of the sinkhole and shaft dimensions. Both methods gave the same results, consistent with the literature. The manuscript also presents a short overview of technologies used for decommissioning shafts and assesses their effectiveness in terms of preventing sinkhole creation. These methods have been used since the nineteenth century until present times. Considering the suffusion phenomenon, the paper proposes a way to drain rainwater from the shaft area, which was another purpose of the work. The necessity to find and verify the ways to secure decommissioned shafts from water is indicated as an important future direction of research.
\end{abstract}

Keywords: Mining engineering, Post-mining area, Shaft, Sinkhole.

\section{Introduction}

The impact of mining on the environment encompasses a wide range of factors, including the transformation of the rock mass along with the surface, changes in hydrological ratios, the problem of waste generation and the emission of mine gases into the atmosphere (Strzałkowski, 2010). The most inconvenient form of this impact is the induction of continuous and discontinuous deformations of the mining area. It should also be emphasised that the

1 Faculty of Mining, Safety Engineering and Industrial Automation, Silesian University of Technology, Akademicka Street 2, 44-100 Gliwice, Poland. E-mail: piotr.strzalkowski@ polsl.pl impact of mining on the environment is not limited to the mine's working time, but occurs long after its liquidation (Palarski, 2000; Wrona et al., 2016). In the case of liquidated underground mines, there is a serious problem: the formation of sinkholes on the surface, mainly over shallow mine galleries (Strzałkowski, 2015). With sufficiently accurate geological and mining documentation, it is possible to assess the area's degree of sinkhole occurrence hazard. Many known methods can be used for this purpose (Chudek et al., 1988), although they are not always successful owing to the random nature of the occurrence of the sinkholes. A major role in this randomness is played by the suffusion phenomenon, which is associated with rainfall, as the rainwater moves loose rocks into a post-mining or natural void, i.e. karst (Gu et al., 2016; Gutiérrez et al., 2013; Kuniansky et al., 2015; Xiao et al., 2016). A separate problem is posed by the environmental hazards associated with the existence of mining shafts. The manner of their liquidation in the previous centuries did not ensure safety conditions.

Typical shaft decommissioning solutions used until the mid-twentieth century are shown in Fig. 1 (Goszcz, 2001; Strozik, 2015). Figure 1a shows the least favourable solution, consisting of building a wooden deck at a depth of over a dozen metres in a shaft (Chudek \& Strzałkowski, 2019). It supported rock material with which the shaft above the deck was filled. The shaft could be covered with a concrete slab (used only since the mid-twentieth century). Another solution was to fill the shaft along the entire length with rock material without covering it with a slab (Fig. 1b). There were two variants of this solution: with and without a dam in the pit bottom. The second solution was used more often. The dam prevented the movement of material filling the shaft to excavations of the pit bottom. The method of cutting 


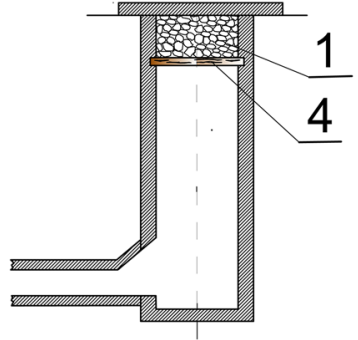

(a)

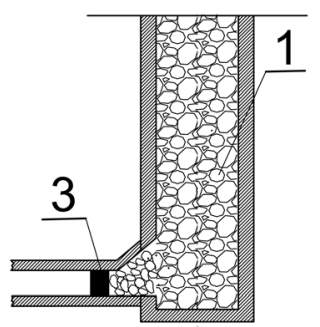

(b)

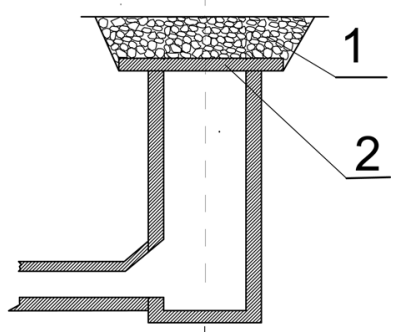

(c)

Figure 1

The shaft decommissioning solutions used until the mid-twentieth century (Goszcz, 2001; Strozik, 2015). a Using a deck at a depth of over a dozen metres, supporting the rock material. Covering the sump with a concrete slab. b Filling the shaft with rock material. Construction of the dam in the pit bottom. c Covering the ground mount with a concrete slab below ground level and covering the slab with rock material. (1) rock material; (2) concrete slab; (3) dam; (4) deck

the shaft support to a certain height below the ground level was also used, covering it with a concrete slab and with rock material (Fig. 1c).

An example of decommissioning the shaft in the middle of the last century is provided by Dean (1967 and Whittaaker and Reddish (1989), as shown in Fig. 2. The solution is a combination of the methods shown in Fig. 1b, c.

Figure 3 contains photographs showing a general view of the surface in the area of liquidated shafts. Figure 3a shows a shaft covered with a concrete slab, Fig. $3 b$ shows a shaft filled with rock material. The remains of a brick support can be seen in the picture as well.

Currently used methods of shaft liquidation are shown in Fig. 4 (Piechota, 2003). Figure 4a-d shows the solutions for shaft decommissioning at the pit

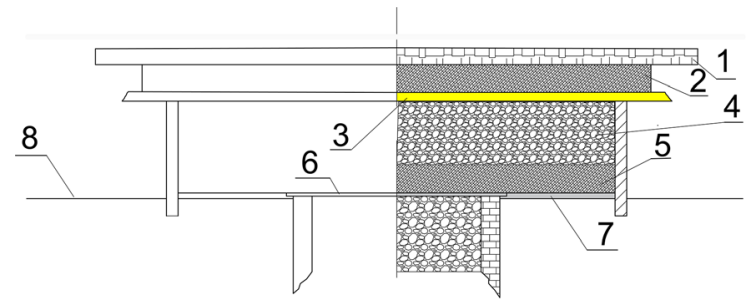

Figure 2

An example of shaft decommissioning solution (Dean, 1967, after Whittaaker and Reddish 1989). (1) slab $(30 \mathrm{~cm})$; (2) concrete $(90 \mathrm{~cm})$; (3) sand cushion over top piles; (4) quarry stone well compacted in $30 \mathrm{~cm}$ layers of sand; (5) slab; (6) $10 \mathrm{~cm}$ shuttering timbers over top of shaft waling; (7) excavated down to rock head and sealed with $15 \mathrm{~cm}$ layer of concrete; (8) rock head bottom level. Figure $4 \mathrm{a}$ shows a pit bottom which is unprotected from the movement of the material filling the shaft. Figure $4 \mathrm{~b}$ shows a dam in the pit bottom which protects the rock material from filling the pit bottom. Both of these solutions concern the liquidation of the shaft along its entire length - from the ground mount to the sump. Both Fig. $4 \mathrm{c}$ and d relate to the liquidation of the shaft to the depth of its shallowest level. In the case shown in Fig. 4c, the pit bottom is covered by a concrete slab, on which the material filling the shaft lies. Figure $4 d$ shows a solution, using a concrete plug, which keeps the rock material in place. Nowadays the ground mount of the shaft is being covered by reinforced concrete slabs (Fig. 4e). This kind of slab has an examination hole, covered by a lid, used to refill the rock material and another one to release gases.

Inactive shafts often act as a way for mine gases $\left(\mathrm{CH}_{4}\right.$ and $\left.\mathrm{CO}_{2}\right)$ to get into the atmosphere. Unextracted coal seams in protective pillars are often where endogenous fires occur, and the amount of gases emitted can be significant. The measurement results given in Wrona et al. (2016) indicate that the amount of $\mathrm{CO}_{2}$ emitted from the shaft was as high as $\sim 83 \mathrm{~m}^{3} / \mathrm{h}$. The emission intensity depends on a number of factors, such as barometric pressure, temperature and, mainly, temperature differences between atmospheric and mine air (Lagny, 2014). This factor is of great importance, especially when the preserved workings are connected to the surface. 


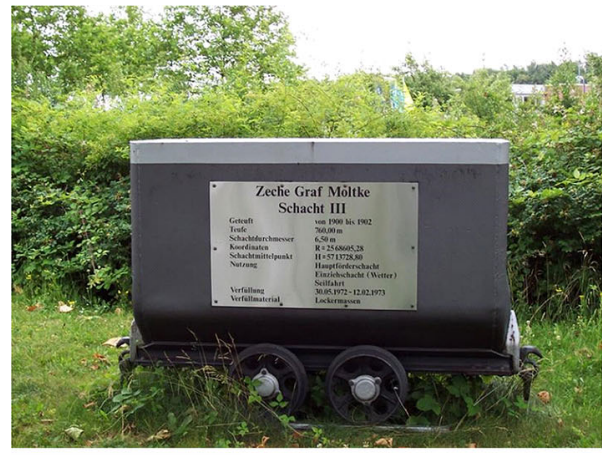

(a)

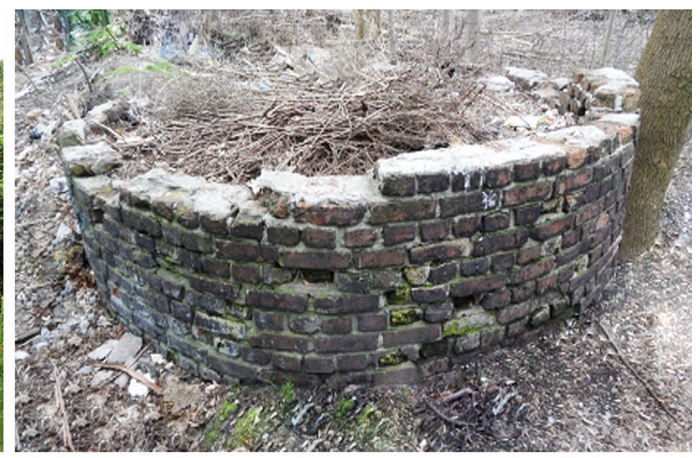

(b)

Figure 3

General view of liquidated shafts. a Shaft covered with a slab; b shaft filled with rock material, with the lining below ground level

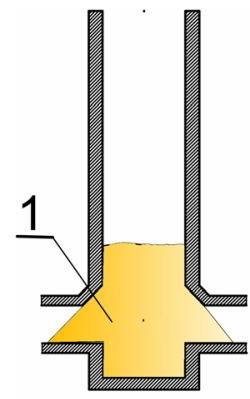

(a)

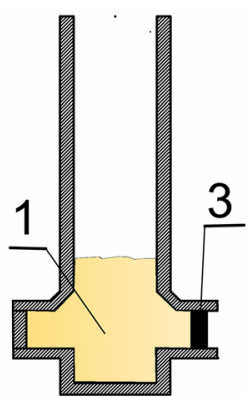

(b)

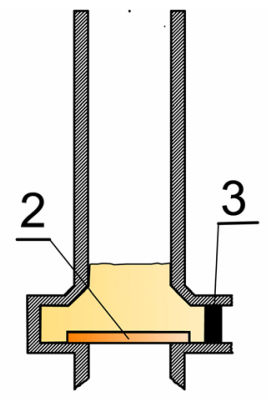

(c)

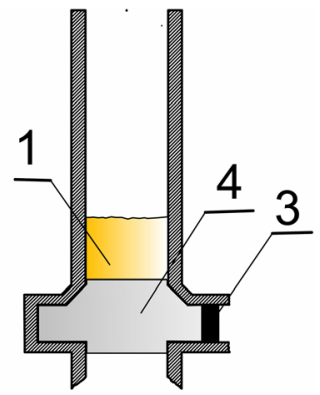

(d)

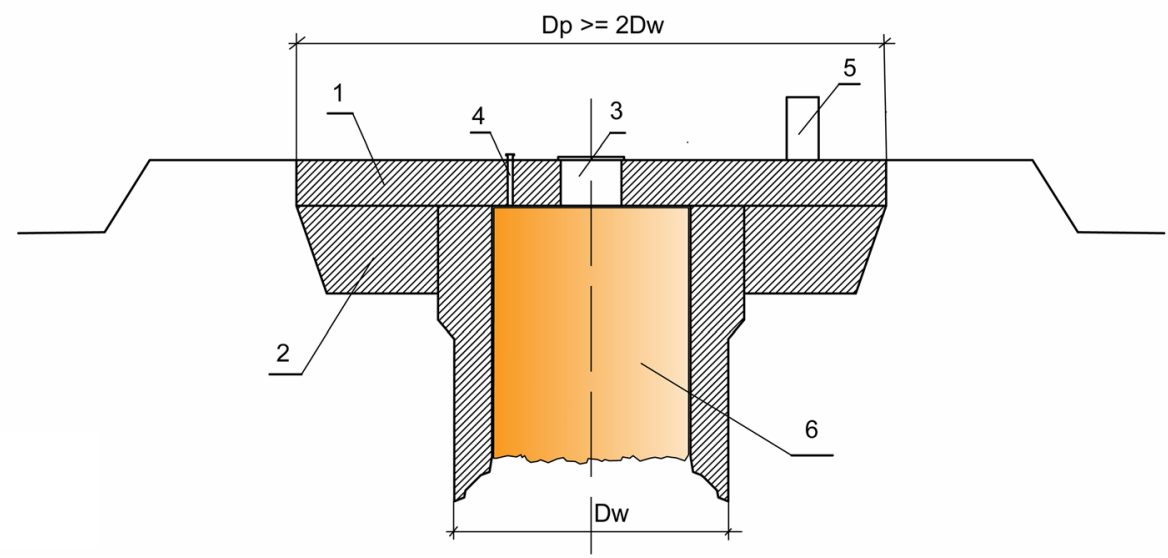

(e)

Figure 4

Modern methods of decommissioning the shafts (Piechota, 2003). a Pit bottom excavations, unprotected from rock material getting through. b Pit bottom excavations protected by a dam. c Pit bottom excavations protected by a dam. Deck on the pit bottom level. d Pit bottom excavations protected by a dam. A concrete plug on the pit bottom level. (1) rock material; (2) deck; (3) dam; (4) concrete plug. e Securing the ground mount of the shaft. (1) reinforced concrete slab; (2) concrete support of the shaft lining; (3) examination hole; (4) gas release hole; (5) board with information about the shaft; (6) rock material 
Former shallow workings and shafts pose a significant hazard of sinkhole formation as a result of subsequent exploitations conducted below them (Hunter, 2015). Similarly, the occurrence of natural caverns in the rock mass creates a hazard to the safety of miners working the excavations, including shafts (Stryffeler \& Sasanakul, 2019). A major problem associated with inactive shafts is the risk of the formation of surface sinkholes. In cases where the shafts were created with a stone lining, the risk is usually smaller. This lining, made of a material characterised by high strength, remains stable for a long time. Backfilling and closing of the shaft with a concrete slab is usually sufficient to protect the surface. Often, however, there is no information regarding the geological and mining conditions and the method of shaft liquidation. In such cases, to assess the possibility of sinkhole occurrence, geophysical investigations should be carried out to find out whether the shaft has been filled with rock material, or if the material has moved into the pit bottom. It is only on the basis of the results of such studies that a way to eliminate the risk can be developed (Kotyrba \& Kortas, 2016).

The older shafts that were liquidated in the nineteenth and early twentieth centuries pose a greater threat. They were often made with wooden lining and in a rectangular shape. The durability of wood is, of course, much lower than that of bricks and concrete, which means that sooner or later the structure loses its stability and a sinkhole is formed. The method of liquidation of these shafts is mostly unknown.

The scale of occurrence of discontinuous deformations can be illustrated by the example below, concerning the area of one of the older GZW mines (Strzałkowski \& Litwa, 2020). In the period between the years 1966 and 2003, 339 sinkholes were created in that area.

The sinkholes occurred:

1. Above exploitation workings - 232 cases $(68 \%)$

2. Above gallery workings -60 cases $(18 \%)$

3. In relation to shafts made as part of legal mining activities, with both wooden support as well as brick or concrete support (lack of detailed data) 11 cases $(3 \%)$

4. In relation to shafts with wooden support, which were made and used illegally - 13 cases $(4 \%)$
5. In relation to raise -10 cases (3\%)

6. With no direct relation to mining activity -13 cases $(4 \%)$

It can be noticed that most sinkholes were created above exploitation workings, which were obviously the most common kind of workings. In the area of liquidated shafts, 24 sinkholes were created, which is only $7 \%$ of the sinkholes. On the other hand, there are the fewest excavations of this kind in each mine. Therefore, it can be assumed, that in many cases of shaft decommissioning, sinkholes were created after some time. It should be added that in the case of shafts liquidated in the 1990s, no sinkholes occurred.

In the case of shafts, the assessment of the possibility of sinkhole occurrence is conducted using the formula proposed by Bell (1988) or numerical methods (Augarde et al., 2003). The comparison of the two calculation methods indicates good compatibility between them (Pilecki \& Baranowski, 2006), not only in the case of shafts, but also voids that are not connected to the surface (Augarde et al., 2003).

In many cases, like the one analysed in this paper, a sinkhole is created as the result of a suffusion phenomenon, which is connected to increased rainfall. Therefore, it is necessary not only to properly liquidate the shaft to ensure the stability of the construction, but also to isolate it from precipitation. Such a proposal is presented as part of this work.

\section{Description of the Analysed Case}

In August 2010, a sinkhole was formed on the site of a liquidated $\mathrm{O}$ shaft. It was located in a green area about $30 \mathrm{~m}$ from the urban area and at a similar distance from the railway line and the express motorway (Fig. 5).

Therefore, there was a threat to public safety. The sinkhole was forming slowly, and was noticed in the morning in the form of a local depression of about $1 \mathrm{~m}$ in depth. The dimensions of the sinkhole were gradually increasing, reaching a diameter of $\sim 9 \mathrm{~m}$. Depth measurement was not carried out. The $\mathrm{O}$ shaft was made to a depth of $57.38 \mathrm{~m}$ with a rectangular shape of $3.0 \times 2.0 \mathrm{~m}$. No data regarding the time of its sinking is available, but taking into account that it 


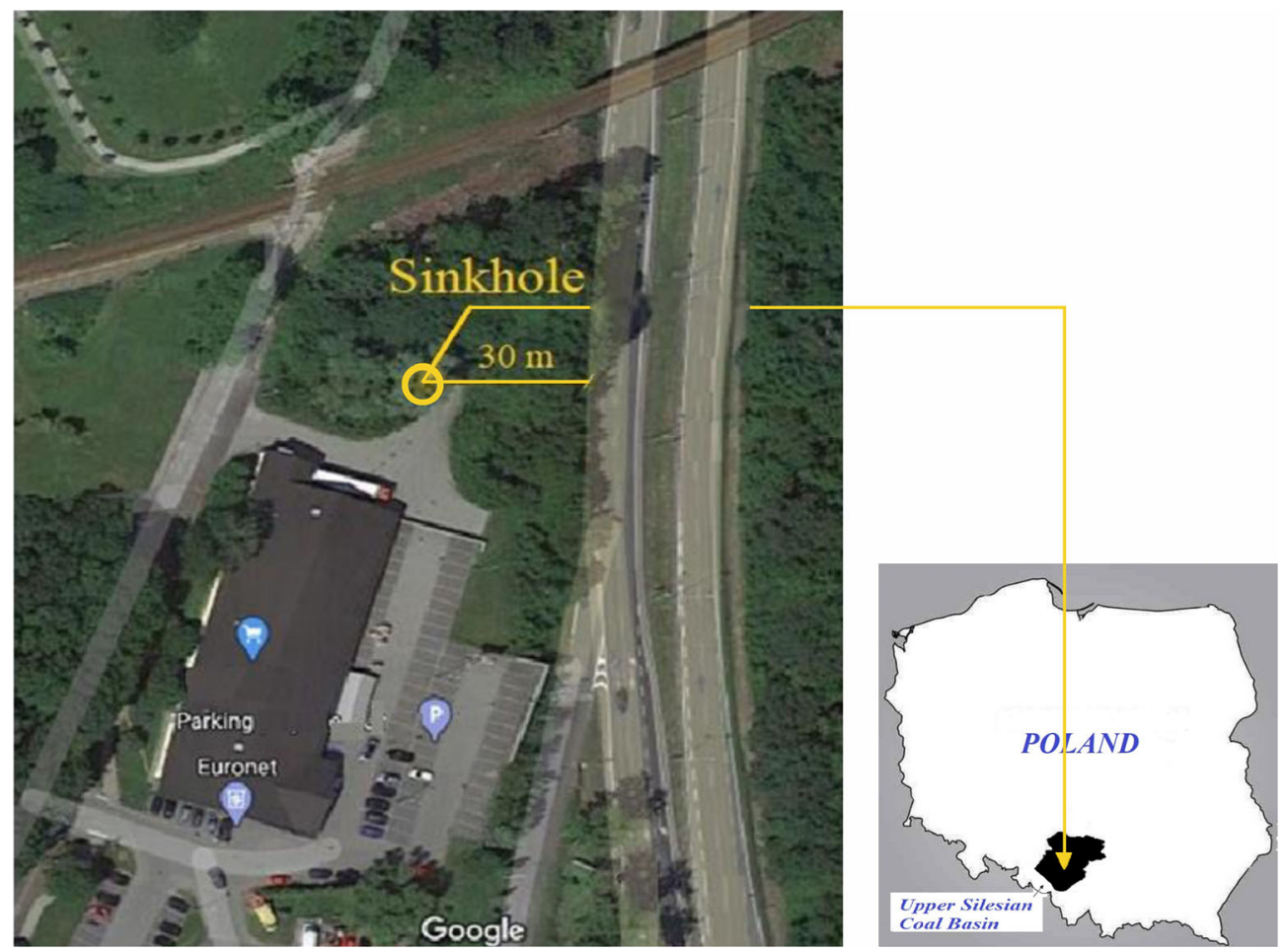

Figure 5

Location of the sinkhole

provided access to seams that were exploited since 1860 , it must have been created in the mid-nineteenth century at the latest. At that time, shafts were created
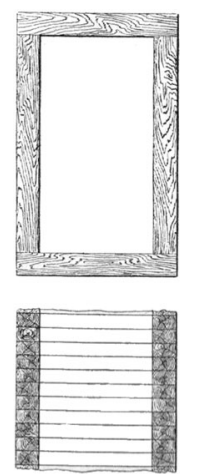

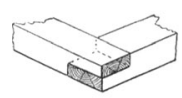

(a)

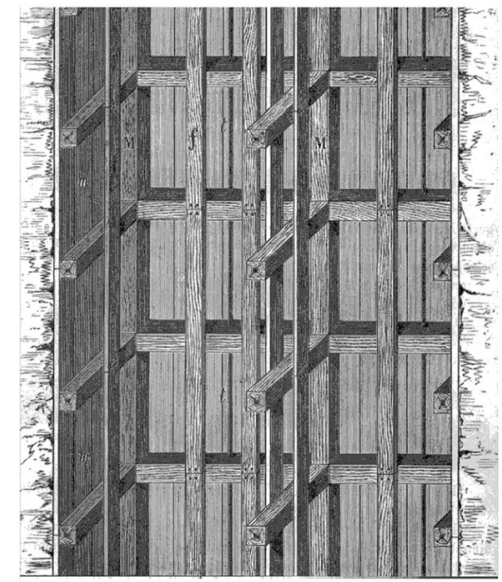

(b)
Figure 6

Wooden lining according to a Heise and Herbst (1910) and b Berdrow (1901) with wooden lining according to the solutions presented in Heise and Herbst (1910) (Fig. 6).

The map analysis provides information that the shaft allowed access to connected seams 216 and 217 at a depth of $33.45 \mathrm{~m}$ and the connected seams 218/1 and $218 / 2$ at a depth of $57.38 \mathrm{~m}$. The exploitation in the area of the shaft was carried out until 1930 using a shortwall system with caving. There is no information regarding the time and method of shaft liquidation. The geophysical research carried out in 1992 showed that the shaft was filled with crushed rock material. There were no voids observed in the rock mass on the site where the shaft was located, nor in its vicinity.

According to data from the Institute of Meteorology and Water Management (https://dane.imgw.pl/ data/dane_pomiarowo_obserwacyjne/), in May 2010, there was an increased amount of precipitation, which amounted to $295 \mathrm{~mm}$. The amounts of rainfall in subsequent months from 2009 are shown in Fig. 7. 


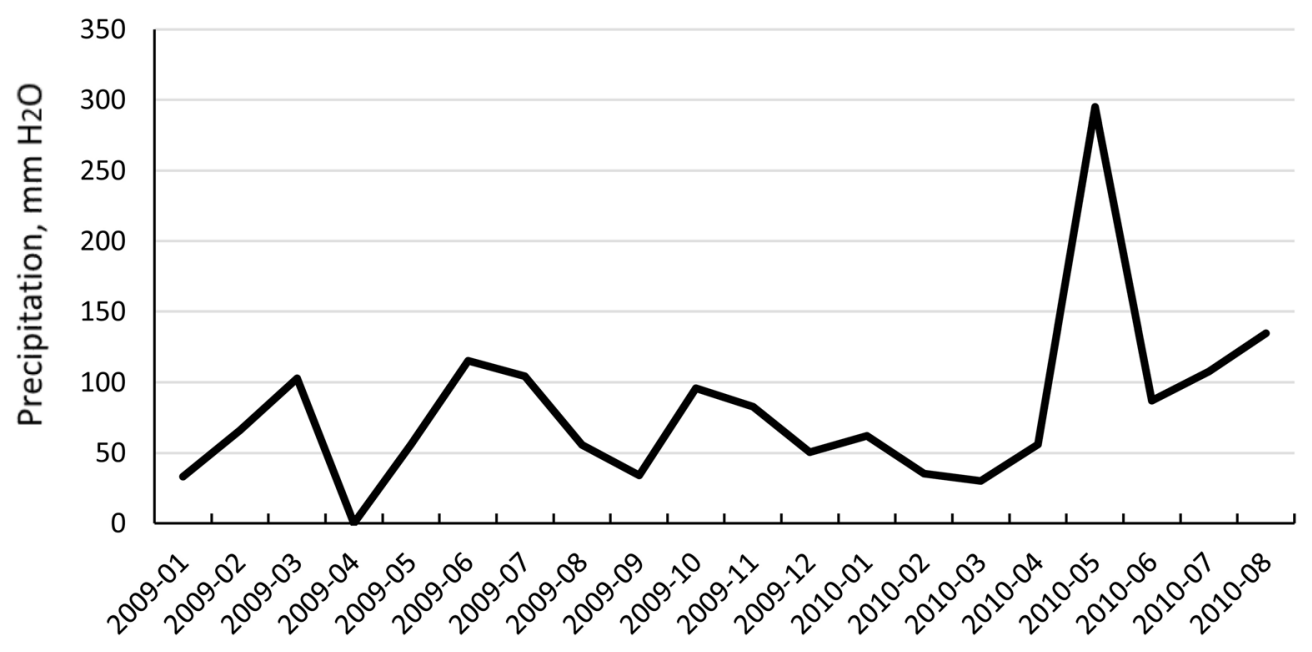

Figure 7

The amount of precipitation at the site of the sinkhole formation in the period from January 2009 to August 2010

\subsection{Rock Mass Structure}

The rock mass was made of a loose overburden formed as a layer of clay with a thickness of about $1 \mathrm{~m}$ and sand with a thickness of $11 \mathrm{~m}$. Below is a dense Carboniferous rock mass made of clay shale with a thickness of $28 \mathrm{~m}$ and sandstone lying below it. At the depths of $33.45 \mathrm{~m}$ and $57.38 \mathrm{~m}$, there are coal seams with a thickness of about $2.3 \mathrm{~m}$. The lithological profile of the rock mass is shown in Fig. 8.

\section{Applied Methods of Analysis and Calculation Results}

When analysing the case of the occurrence of the sinkhole, it was decided to conduct relevant calculations using the proposal presented by Bell (1988), and then make a calculation using Phase 2 software.

The dimensions of the sinkhole hazard zone are determined by the formula (Bell, 1988) - Fig. 9:

$$
D=2 \cdot h \cdot \operatorname{tg}\left(90^{\circ}-\phi\right)+2 r
$$

where, $h$ is the the thickness of the loose overburden, $\mathrm{m} ; \varphi$ is the average internal friction angle of the loose overburden material, degrees; and $r$ is the radius of the shaft working, $\mathrm{m}$.

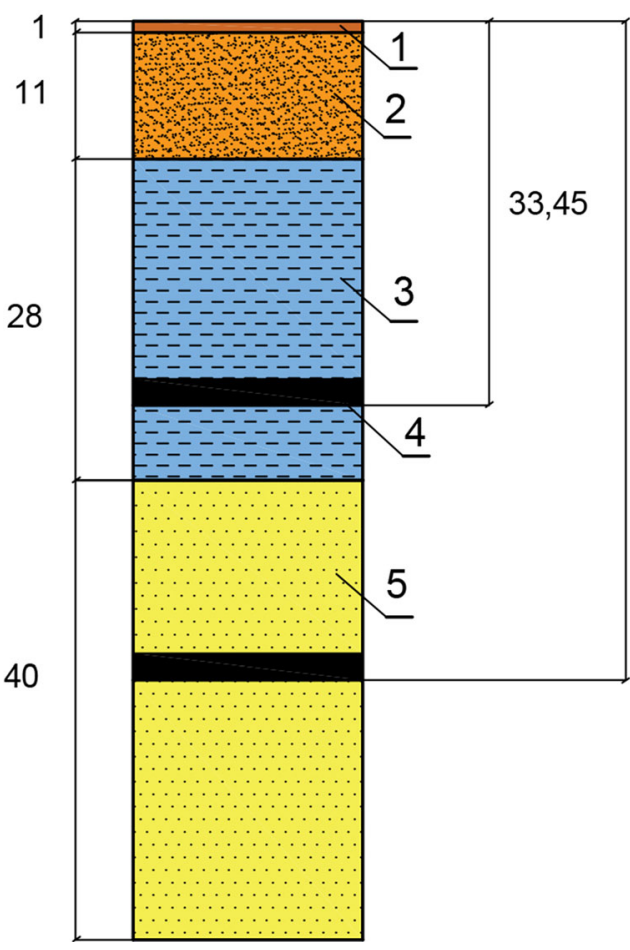

57,38

Figure 8

The lithological profile of the rock mass. Layer thickness is given in metres. (1) clay; (2) sand; (3) clay shale; (4) coal seam (thickness $2.3 \mathrm{~m}$ ); (5) sandstone

The following assumptions regarding material constants of rocks were made for calculations (Kidybiński, 1982) - Table 1: 


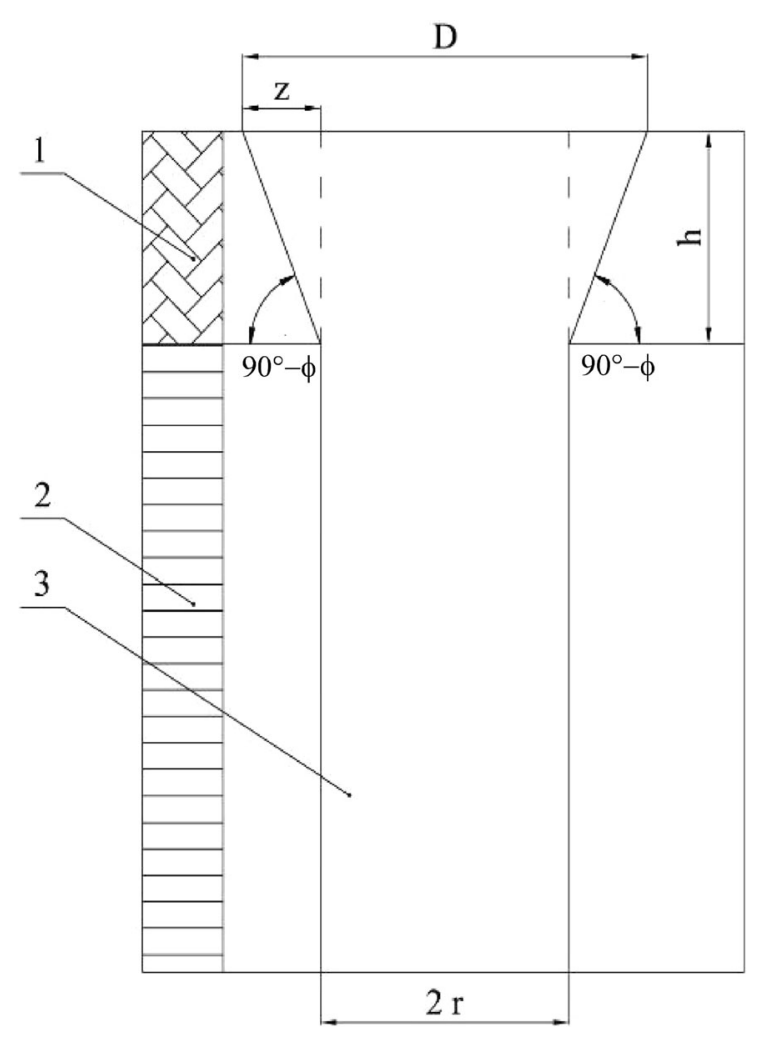

Figure 9

Diameter of the sinkhole according to formula (1). (1) loose overburden; (2) strong rock mass; (3) shaft

Table 1

Properties of rocks assumed in the calculations

\begin{tabular}{llllllr}
\hline Rock & $\gamma\left(\mathrm{MN} / \mathrm{m}^{3}\right)$ & $E(\mathrm{MPa})$ & $v$ & $R_{r}(\mathrm{MPa})$ & $\varphi\left(^{\circ}\right)$ & $c, \mathrm{MPa}$ \\
\hline Loam & 0.027 & 100 & 0.20 & 0.002 & 23 & 0.005 \\
Sand & 0.025 & 70 & 0.20 & 0.005 & 28 & 0.010 \\
Clay slate & 0.025 & 11,300 & 0.18 & 1.800 & 23 & 1.000 \\
Sandstone & 0.025 & 12,200 & 0.15 & 3.500 & 30 & 2.500 \\
Coal & 0.013 & 3000 & 0.25 & 0.500 & 27 & 2.000 \\
Backfill & 0.027 & 10 & 0.30 & 0.000 & 35 & 10.500 \\
\hline
\end{tabular}

$\gamma$ bulk density, $E$ Young's modulus, $v$ Poisson coefficient, $R_{r}$ tensile strength, $\varphi$ internal friction angle, $c$ cohesion

It should be recognised that, as a result of rainwater infiltration, the material filling the shaft has been displaced, filling the voids between the rock fragments. It is also impossible to rule out its displacement to the pit bottom. Thus, the level of the rock material was lowered near the surface. In this way, there was free space for the loose overburden rocks that could move there. First, the formula (1) was used to calculate the depth of the sinkhole associated with the displacement of the rock material as a result of suffusion phenomenon. It was calculated that if the diameter of the sinkhole was $9 \mathrm{~m}$, with the longer side length of the disc shaft equal to $3 \mathrm{~m}$, then the rock material should move to a depth of $1.60 \mathrm{~m}$.

The author assumed that a continuous rock mass model can be used for numerical calculations. No mining has been carried out in the vicinity of the shaft (a pillar has been left around it); thus, it may be concluded that there are no discontinuity zones in the rock mass. Therefore, the use of the finite element method (FEM) or finite difference method (FDM)is warranted, but there is no need to use, e.g., UDEC software (Tajduś et al., 2012). Among the software using FEM and FDM, Phase 2 and FLAC are the ones most often applied in rock mechanics. Phase 2 is more user-friendly; the manner of preparing data for calculations is much easier. The above considerations were crucial in the decision to apply Phase 2 software in the analyses presented in the paper. Apart from the easy creation of a data set, this software has the following advantages:

- It allows consideration of the layered structure of the rock mass, assuming the continuity of layers with different strength and deformation parameters. This roughly reflects the real properties of the rock mass.

- The calculations can take into account the elasticplastic properties of the rock mass using the Coulomb-Mohr model, which properly describes the behaviour of the rock mass.

The disadvantage of this software, however, is reducing the considerations to a linear problem - the rock mass face. The use of FLAC 3D would allow us to avoid this simplification, but at the cost of more labour-intensive data preparation and extension of the calculation time.

This assumption was also adopted when using the Phase2 6.0 software, assuming values of strength parameters in accordance with Table 1 and the Coulomb-Mohr condition as well as plastic properties of rocks and elastic properties of the rock material. 
This condition assumes that the destruction of rock material occurs as a result of exceeding its shear stress $\tau$, according to the equation

$$
\tau=f\left(\sigma_{n}\right)=\sigma_{n} \cdot \operatorname{tg} \varphi+c,
$$

where $\tau$ is the shear stress (MPa); $\sigma_{n}$ is the normal stress $(\mathrm{MPa})$; and $\varphi$ is the angle of internal friction $\left({ }^{\circ}\right), c$ cohesion $(\mathrm{MPa})$.

Therefore, the value of normal stress, and indirectly the depth and material parameters, that is, the angle of internal friction and cohesion, have an impact on the destruction of the rock material.

Only the impact of mass forces was taken into account in the calculations. The finite element mesh was densified in the area of the shaft in relation to the one generated by the software to increase the accuracy of calculations.

The programme was used to build a model for the cross-section of the rock mass, give appropriate rock mass properties to the layers (Fig. 10a, shaft location is marked) and calibrate the model. Then, the model of a shaft was generated and the adequate properties were assigned to the material filling the shaft (Fig. 10b).

The results of total displacement calculations (difference between specific stages; calibrated model - Fig. 10a, model of a shaft filled with rock material - Fig. 10b) obtained using the Phase2 6.0 software are shown in Fig. 10c.

\section{Discussion of the Calculation Results}

The results of the calculations presented above indicate that the displacement of the rock material into the shaft to a depth of $1.6 \mathrm{~m}$ caused the rock masses of the loose overburden to move into the resulting void, forming a sinkhole on the surface. The maximum resultant dislocations of the loose overburden at the site of the shaft opening amounted to about $0.36 \mathrm{~m}$. The numerical calculations allow us to conclude that the diameter of the sinkhole is roughly equal to the diameter defined in formula (1). Assuming that the limit value reflecting the range of displacement is approximately $3 \mathrm{~cm}$ (which is derived from the presentation of the results in Fig. 10c, related to accuracy), it can be assumed that the diameter of the sinkhole is approximately $8 \mathrm{~m}$. Assuming a lower limit value, the diameter of the sinkhole is over $9 \mathrm{~m}$.

Rock material could fill the pit bottom, which was not secured by a dam at that time. Therefore, the importance of securing pit bottoms properly needs to acknowledged. Solutions shown in Fig. $4 b-d$ can be recommended, while the solution shown in Fig. 4a does not ensure that the appropriate safety conditions are fulfilled. In the analysed case study, the shaft was not covered by a reinforced concrete slab, which facilitated the migration of rainwater into the shaft. In the case of shafts liquidated nowadays, they are covered with slabs, and so far no sinkhole occurrences have been reported. It should also be emphasized that the shafts decommissioned today, which come from the second half of the twentieth century, have linings made of brick or concrete, and are therefore quite durable. They may lose stability after a long time. The real problem are shafts that have wooden support, which is way less durable. These shafts, from the nineteenth century or illegally made in the early twentieth century, pose a great risk of sinkhole creation, even after filling them with rock material, which is proved by the case study from this manuscript. This leads the author to conclude that it is necessary not only to use slabs of sufficiently large dimensions but also to drain rainwater away from them. This can be achieved by, for example, creating banding around the slab, that is, sewers made of prefabricated elements Fig. 11, which will allow water to drain into a drainage ditch or well, which will be drained afterwards.

\section{Summary and Conclusions}

Former mining shafts, especially those from the nineteenth and early twentieth century, liquidated in an ineffective manner, continue to pose a public safety hazard due to the formation of sinkholes. The case presented in the article is one of many examples of the formation of such a hazard. The shaft was filled with rock material, but abundant precipitation caused dislocation of the loose overburden, which led to the creation of a sinkhole with a diameter of about $9 \mathrm{~m}$. 

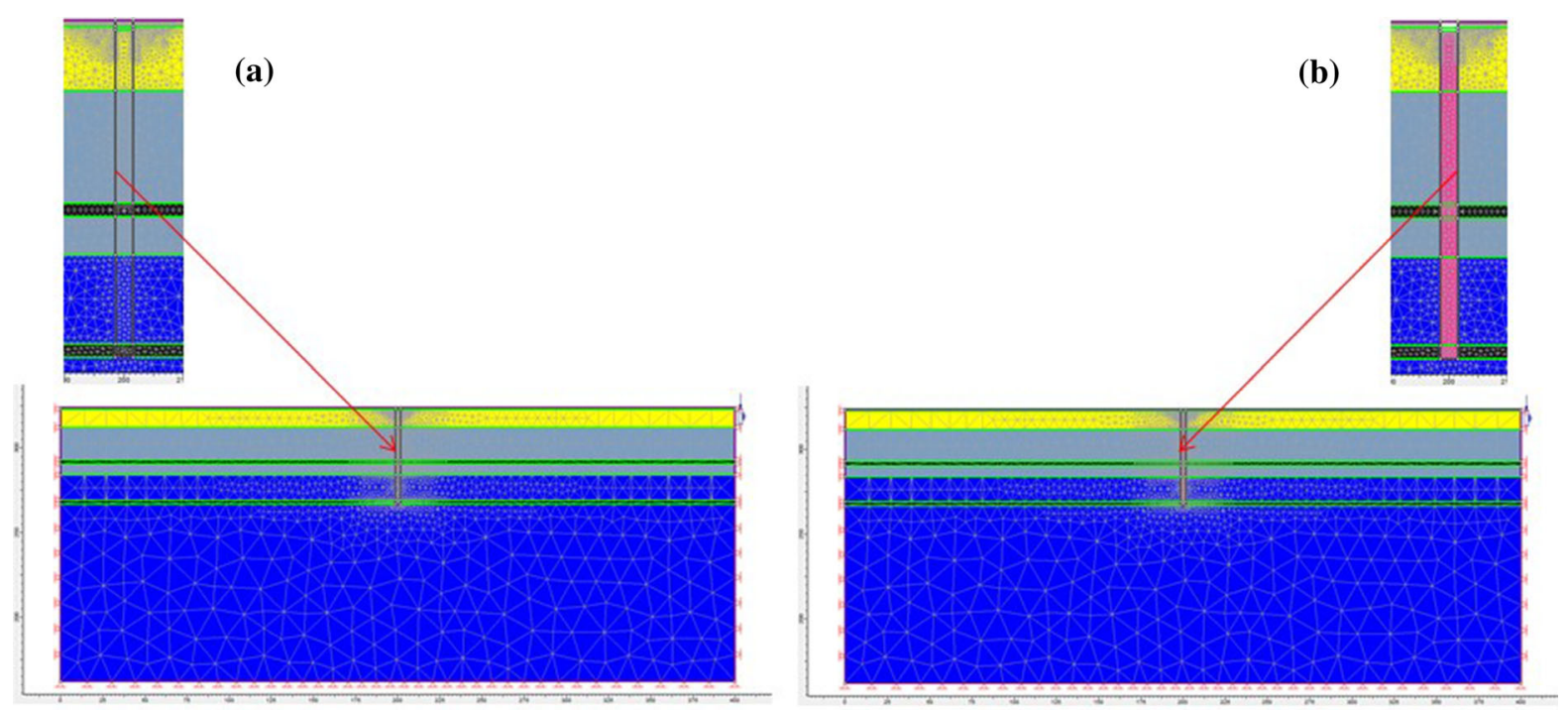

(c)

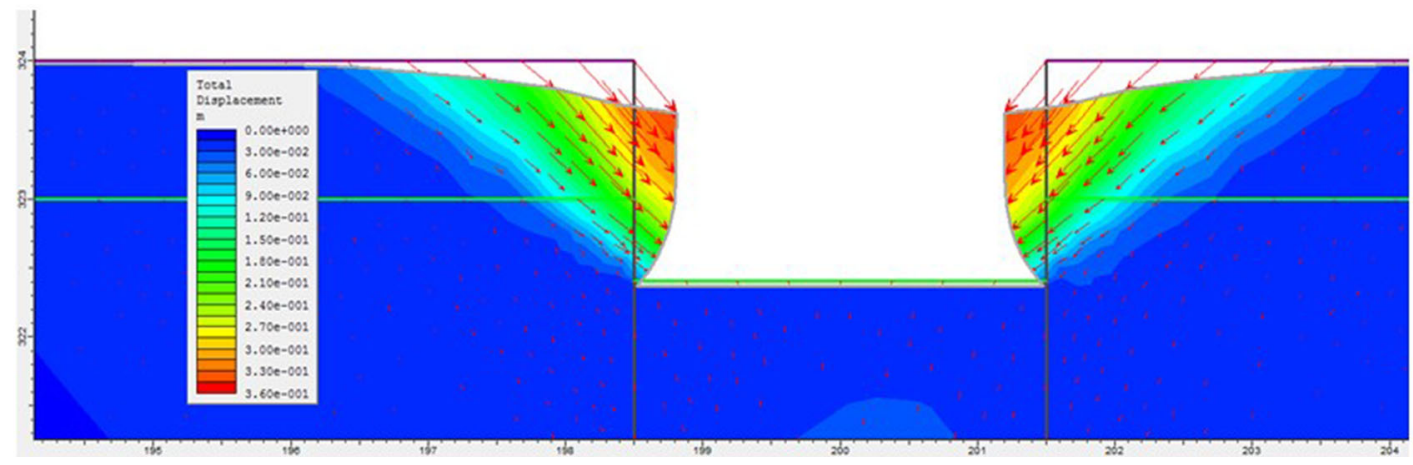

Figure 10

Stages of calculations in Phase2 6.0. a Model created to calibrate the cross-section (stage 1). b Model taking into account a shaft filled with rock material. $\mathbf{c}$ Total rock mass displacements according to the calculations from the Phase 26.0 software

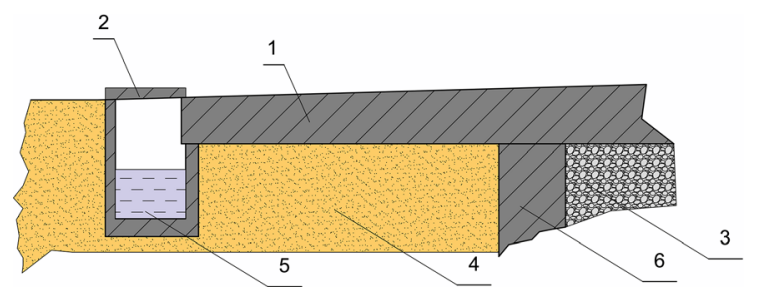

Figure 11

Concrete banding with a channel for draining rainwater. $(1,2)$ concrete slab; (3) rock material; (4) sand; (5) channel for draining rainwater; (6) support of the shaft

The sinkhole was created in a time that was difficult to predict, in a random manner.

Currently, shafts constructed before the first half of the twentieth century and having wooden support, pose a risk of sinkhole creation. These shafts have been decommissioned without being covered by a reinforced concrete slab, which should be used every time. Similarly crucial is securing the pit bottom from the movement of rock material. It should also be noted that rainwater should be drained to limit the possibility of suffusion occurrence. According to the author, this is a relevant problem which is not being solved currently.

Author Contributions I declare that I am the only author of the above article and all those who contributed to its creation have been credited in the text and references. 


\section{Funding}

Research partly financed by the Ministry of Science and Higher Education, implemented at the Silesian University of Technology.

\section{Declarations}

Conflict of Interest The author declares that he has no conflict of interest.

Open Access This article is licensed under a Creative Commons Attribution 4.0 International License, which permits use, sharing, adaptation, distribution and reproduction in any medium or format, as long as you give appropriate credit to the original author(s) and the source, provide a link to the Creative Commons licence, and indicate if changes were made. The images or other third party material in this article are included in the article's Creative Commons licence, unless indicated otherwise in a credit line to the material. If material is not included in the article's Creative Commons licence and your intended use is not permitted by statutory regulation or exceeds the permitted use, you will need to obtain permission directly from the copyright holder. To view a copy of this licence, visit http://creativecommons.org/licenses/by/4.0/.

Publisher's Note Springer Nature remains neutral with regard to jurisdictional claims in published maps and institutional affiliations.

\section{REFERENCES}

Augarde, C. A., Lyamin, A. V., \& Sloan, S. W. (2003). Prediction of undrained sinkhole collapse. Journal of Geotechnical and Geoenvironmental Engineering, 3, 197-205. https://doi.org/10. 1061/(ASCE)1090-0241(2003)129:3(197).

Bell, F. G. (1988). Land development. State of the art in the location of old mine shafts. Bulletin of the International Association for Engineering Geology, 37, 91-98.

Berdrow, W. (1901). Buch der Erfindungen. . Verlag von Otto Spamer.

Chudek, M., Janusz, W., \& Zych, J. (1988). Study on diagnosis and prognosis of the formation of discontinuous deformation due to underground mining. Publisher of the Silesian Technical University, Scientific Notebooks No. 141, Gliwice (in Polish).

Chudek, M., \& Strzałkowski, P. (2019). Assessment of the hazard level posed to a post-mining area by discontinuous surface deformations. In IOP Conference Series; Earth and Environmental Science (Vol. 261, Art no. 012004). https://doi.org/10. 1088/1755-1315/261/1/012004

Dean, J. N. (1967). Old mine shaft and their hazard. The Mining Engineer, 126, 368-376.

Goszcz, A. (2001). Possibilities and limitations in restoring usability to mining areas. In Symposium Workshop 2001 on: Restoring utility to mining areas. IGSMiE PAN (pp. 95-108) (in Polish).
Gutiérrez, F., Cooper, A. H., \& Johnson, K. S. (2013). Identification, prediction, and mitigation of sinkhole hazards in evaporite karst areas. Environmental Geology, 70(4), 1463-1478.

Gu, Z., Liu, Q., \& Lu, Y. (2016). Analysis and prevention of sinkhole collapses during the reconstruction and extension of Guang-Qing freeway, China. Environment and Earth Science, 75, 788. https://doi.org/10.1007/s12665-016-5625-2.

Hunter, J. (2015). Old mines and new sinkholes along the Hucklow Edge vein, Derbyshire. American Geologist, 18(4), 213-226.

Heise, F., \& Herbst, F. (1910). Bergbaukunde. Zweiter Band. . Verlag von Julius Springer.

Kidybiński, A. (1982). Basics of mining geotechnics. Śląsk Publishing House (in Polish).

Kotyrba, A., \& Kortas, Ł. (2016). Sinkhole hazard assessment in the area of abandoned mining shaft basing on microgravity survey and modelling - case study from the Upper Silesia Coal Basin in Poland. Journal of Applied Geophysics, 130, 62-70. https://doi.org/10.1016/j.jappgeo.2016.04.007.

Kuniansky, E. L., Weary, D. J., \& Kaufmann, J. E. (2015). The current status of mapping karst areas and availability of public sinkhole-risk resources in karst terrains of the United States. Hydrogeology Journal, 24(3), 613-624.

Lagny, C. (2014). The emissions of gases from abandoned mines: role of atmospheric pressure changes and air temperature on the surface. Environment and Earth Science, 71, 923. https://doi.org/ 10.1007/s12665-013-2495-8.

Palarski, J. (2000). Liquidation of mines and environmental threats. In Conference materials of the School of Underground Mining (in Polish).

Piechota, S. (2003). Basic principles and technologies for exploitation of solid minerals. . Library of the School of Underground Mining (in Polish).

Pilecki, Z., \& Baranowski, A. (2006). Estimation of dimension of regular-type sinkhole activated by abandoned shafts. Publications of the Institute of Geophysics, Polish Academy of Science, M-29, 395-404.

Strozik, G. (2015). Filling underground voids in the rock mass affected by mining exploitation. Publisher of the Silesian Technical University (in Polish).

Stryffeler, C.B., \& Sasanakul, I. (2019). Sinkhole development and propagation during drilled shaft construction in West-Central Florida during the 2017 Atlantic hurricane season. In Eighth International Conference on Case Histories in Geotechnical Engineering March, (pp. 24-27). Philadelphia. https://doi.org/10. 1061/9780784482094.021.

Strzałkowski, P. (2010). Outline of protection of mining areas. . Publisher of the Silesian Technical University.

Strzałkowski, P. (2015). Mathematical model of forecasting the formation of sinkhole using Salustowicz's theory. Archives of Mining Sciences, 1, 63-71.

Strzałkowski, P., \& Litwa, P. (2020). Environmental protection problems in the areas of former mines with emphasis on sinkholes. Selected examples. International Journal of Environmental Science and Technology. https://doi.org/10.1007/ s13762-020-02860-4.

Tajduś, A., Cała, M., \& Tajduś, K. (2012). Geomechanics in underground construction. Designing and building tunnels. . Issued by AGH.

Whittaker, B. W., \& Redish, D. J. (1989). Subsidence: Occurrence, Prediction, and Control. Elsevier. 
Wrona, P., Różański, Z., \& Pach, G. (2016). Closed coal mine shaft as a source of carbon dioxide emissions. Environment and Earth Science, 75, 1139. https://doi.org/10.1007/s12665-016-5977-7.
Xiao, H., Kim, Y. J., Nam, B. H., \& Wang, D. (2016). Investigation of the impacts of local-scale hydrogeologic conditions on sinkhole occurrence in East-Central Florida, USA. Environment and Earth Science, 75, 1274.

(Received May 12, 2020, revised March 7, 2021, accepted March 22, 2021, Published online April 20, 2021) 